\title{
シールドエ事用コンクリート系セグメント の耐久性能と耐火性能
}

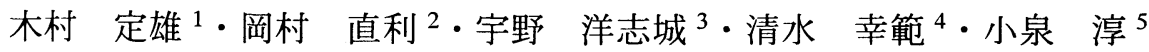 \\ 1正会員 工博 金沢工業大学 環境系土木工学科 (T921-8501 石川県石川郡野々市町扇が丘 7-1) \\ s.kimura@neptune.kanazawa-it.ac.jp \\ ${ }^{2}$ 正会員 佐藤工業懒) 首都圏業務部 (广101-0032 東京都千代田区岩本町 1-2) \\ N.Okamura@satokogyo.co.jp \\ 3 正会員 佐藤工業株) 中央技術研究所 (广243-0211 神奈川県厚木市三田 47-3) \\ Uno@satokogyo.co.jp \\ ${ }^{4}$ 正会員 工修 佐藤工業株) 東京支店 (下160-0023 東京都新宿区西新宿 6-24-1) \\ Yukinori.Shimizu@satokogyo.co.jp \\ 5 正会員 工博 早稲田大学 理工学部土木工学科 ( $\bar{T} 169-8555$ 東京都新宿区大久保 3-4-1) \\ koizumi@mn.waseda.ac.jp
}

\begin{abstract}
近年，シールドトンネルの工事ではその工事費を縮减することを目的として，トンネル用途に応じて二次覆工を省略 する傾向がある. しかしながら, その工事実績の歴史も浅く, 二次覆工を省略した際の覆工の長期的な性能の低下など, 二次覆工の機能を明確にした上で，それに代替えする方策が完全になされているとは言い難い，このため，これまで二 次覆工が担ってきた機能は，一次覆工であるセグメントを主体にそれを補う必要がある. 一方，セグメントの耐久性能 に関する直接的な資料がほとんど見あたらないのも害状である. 本研究は一次覆工を省略する際に用いられている鉄筋 コンクリート製セグメントのコンクリートの耐久性能拉よひ耐火性能を実験によって把握したものである. 実験の結果 から,セグメントの製造に用いるコンクリートは而久久性能およひ耐火性能がともに高いことがわかった.
\end{abstract}

Key Words: shield tunnel, design of tunnel lining, durability, fire resistance, highly flowable concrete

\section{1.はじめに}

シールドトンネルの覆工は, 一般に一次覆工と二 次覆工からなる。一次覆工はセグメントと呼ばれる プレキャスト部材をボルトなどを用いて締結して構 築される. 二次覆工は一次覆工の内側に現場打ちコ ンクリートで構築されるのが一般的である.

従来，覆工の役割はトンネルに作用する荷重に対 して十分安全に抵抗できること，トンネルの使用目 的に応じた機能を有すること, トンネルの施工条件 に応じた覆工構造を有することの 3 つに大別して考 えられてきた 1). とりわけ，一次覆工が組み立てら れてから，二次覆工の施工が完了するまでに長期間 を要することが多く，この期間中に作用する荷重の 経時変化が不確定であること, 一次覆工と二次覆工 の荷重分担の推定が困難であること等の理由から, 一次覆工のみを覆工構造の主体として考え, それが 長期にわたってトンネルに作用する荷重に耐えるよ うに設計するのが一般的であった．また，二次覆工
は一次覆工を保護して，その防食と補強との役目を 果たし, 蛇行修正, 防水, その他のトンネルの使用 目的に応じた機能を有する仕上げ工として施されて きた。

一方, 近年では, 社会的に公共事業費の縮減が求 められ, シールド工事においてもその工事費を縮減 する必要が生じ, その一つの方策として, 二次覆工 を省略する事例が増加してきている.

二次覆工を省略することによって得られる効果は, トンネルの覆工全体の厚さを低減することによるト ンネルの掘削断面や地下占用幅の縮小，同一掘削断 面に対する内空断面の拡大なぞが挙げられる。 その 結果, 掘削費や掘削残土の処理費の縮減およびシー ルドの外径縮小によるその製作費の縮減など，建設 工事費の縮減が可能になるケースもある. さらには, 二次覆工の構築に要する工期を短縮することも可能 となり, 地上占用期間の短縮やトンネルの早期の供 用開始などの効果も期待できる 2 ).

最近では, これらの効果を期待して, 共同溝, 電 
表-1 トンネルの用途別二次覆工の要求機能 (参考) 11)

\begin{tabular}{|c|c|c|c|c|c|c|c|c|c|c|}
\hline 機能 用途 & $\begin{array}{l}\text { 下水道 } \\
\text { (污水) }\end{array}$ & $\begin{array}{l}\text { 下水道 } \\
\text { (雨水) }\end{array}$ & $\begin{array}{l}\text { 下水道 } \\
\text { (合流) }\end{array}$ & 電 力 & 通 信 & ガ ス & 共同溝 & 地下河川 & 鉄 道 & 道 路 \\
\hline (1)セグメントの防食 & (2) & 0 & (a) & (a) & (a) & (2) & (O) & (a) & () & (a) \\
\hline (2) トンネルの防水 & 0 & 0 & 0 & (a) & (a) & (2) & (2) & (2) & (a) & (a) \\
\hline (3)線形確保 & (2) & (2) & (a) & & & & & (a) & & \\
\hline (4)平滑性の確保 & (2) & (2) & (a) & & & & & (2) & & \\
\hline (5)セグメントの補強 & $\mathrm{O}$ & $\mathrm{O}$ & 0 & 0 & 0 & $\mathrm{O}$ & 0 & 0 & $\mathrm{O}$ & 0 \\
\hline (6)浮上り防止 & 0 & 0 & $\mathrm{O}$ & $\mathrm{O}$ & 0 & $\mathrm{O}$ & $\mathrm{O}$ & $\mathrm{O}$ & 0 & 0 \\
\hline (7)内部施設設置 & & & & (a) & (a) & (2) & (a) & & (2) & (a) \\
\hline (8)隔壁 & 0 & $\mathrm{O}$ & 0 & $\mathrm{O}$ & 0 & $\mathrm{O}$ & $\mathrm{O}$ & & $\mathrm{O}$ & 0 \\
\hline (9)摩耗対策 & 0 & (2) & (a) & & & & & (2) & & \\
\hline (10)防振・防音 (参考) & & & & & & & & & (2) & \\
\hline (11)酎火 (参考) & & & & & & & & & & (2) \\
\hline
\end{tabular}

注）○は主目的である要求機能. ○は付加的あるいは特殊な場合の要求機能

力，通信，鉄道，地下河川などのシールドトンネル では二次覆工を省略する傾向が強まっている.

ここで, 二次覆工を省略する際の覆工の耐久性能, すなわち，セグメントのみを覆工構造とした場合の 覆工の耐久性能を考えてみる．覆工の耐久性能を低 下させる要因は，トンネルの外側の地盤環境による 影響とトンネルの用途に応じて定まる内側の環境に よる影響に分けて考えることができる.したがって， 二次覆工を省略する場合には, 内側からの影響につ いても一次覆工がそれに対応する必要がある.

一般に, 二次覆工を省略する場合には, 一次覆工 として鉄筋コンクリート製セグメント(以下， RC セ グメントと呼ぶ)が多用されている．これを採用した 場合, 覆工の耐久性能は, a)その製造に用いるコン クリートや鉄筋などのセグメント本体の耐久性能,

b)個々のセグメントを連結する継手部の金物類や止 水のためのシール材などの耐久性能および c)覆工と 地山との間に注入される裏込め材の耐久性能に大別 して考えることができる. 本研究はこれらのうち,

a)セグメントの本体を形成するコンクリートの耐久 性能に着目したものである. そこでまず，これまで に RC セグメントの製造に用いられてきたコンクリ 一トの耐久性能に対する考え方を整理してみる.

$\mathrm{RC}$ セグメントの開発当初(1951 年頃)を顧みると, 目標強度が $550 \mathrm{kgf} / \mathrm{cm}^{2}$ と高く, かつ経済的なものと するため, そのコンクリートの配合は，セメント量 が $390 \mathrm{~kg} / \mathrm{m}^{3}$ 程度と多く, 水セメント比が $39.5 \%$ と小 さく, 単位水量の少ない硬練りコンクリート(スラン プは $5 \mathrm{~cm}$ )の仕様としていた. またこの当時は, 硬化 コンクリートの性能を評価する指標として主に圧縮 強度に着眼し, その安定した品質管理方法の検討に 終始していたようである 3 ).

また，これまでに採用されてきている RC セグメ ントの製造に用いているコンクリートの配合は, 水 セメント比が概ね $40 \%$ 程度と小さいことから, 良質
の骨材などを用いれば, 鉄筋コンクリート構造とし ての耐久性能は高いものと考えられてきている 4). したがって，とくにセグメントの製造に用いるコン クリートの耐久性能を検証した資料は，海底下のシ ールドトンネルの工事に際して行われた試験結果な ぞ, 数例しか見あたらない 5),6),7),8).

以上の実状を踏まえ，筆者らは RC セグメントを 主体として，セグメントの製造に用いるコンクリー トに主眼をおき，その基本的な耐久性能と耐火性能 とを各種試験により確認した．本論文はこれらの試 験結果を示すとともに, それらに考察を加えたもの である.なお，本論文中で対象としたコンクリート は, 従来からセグメントの製造に多用されてきてい る硬練りコンクリート(以下, 在来コンクリートと呼 ぶ)と近年に開発された高流動コンクリート 9),10)の 両者である.

\section{2. 二次覆工の機能とその代替えとしてセグメント に求められる機能の考え方}

シールドトンネルの二次覆工に求められる機能は, トンネルの用途や使用条件および環境条件などから 定まる主機能と, 事前に要求してはいないが二次覆 工を施すことによって付加的にその効果が生じたり， または特殊な場合に考慮する機能とに大別される.

表-1 はトンネルの用途別に, これらの機能を示した ものである 11). なお, これらの機能はトンネルの用 途に応じて，その管理者が独自に判断しているもの である.このため, 同じ機能に対してトンネル用途 の相互関係を直接比較できるものではない. すなわ ち, セグメントの防食という機能を見ると, 下水道 (雨水)のみが重要度は低いとしているように見える が, 下水道以外の他の用途に比べて定量的に重要度 が低いことを意味するものではなく, 各々の管理者 
表-2 セグメント用コンクリートの示方配合

\begin{tabular}{|c|c|c|c|c|c|c|c|c|c|c|}
\hline \multirow{2}{*}{$\begin{array}{l}\text { 配合 } \\
\text { 種類 }\end{array}$} & \multirow{2}{*}{$\begin{array}{c}\text { スラフプ (70-) } \\
(\mathrm{cm})\end{array}$} & \multirow{2}{*}{$\begin{array}{c}\text { 空気量 } \\
(\%)\end{array}$} & \multirow{2}{*}{$\begin{array}{c}\mathrm{W} / \mathrm{C} \\
(\%)\end{array}$} & \multirow{2}{*}{$\begin{array}{l}s / a \\
(\%)\end{array}$} & \multicolumn{2}{|c|}{ 単 } & \multicolumn{2}{|c|}{ 位 } & \multicolumn{2}{|c|}{$\left(\mathrm{kg} / \mathrm{m}^{3}\right)$} \\
\hline & & & & & W & $\mathrm{C}$ & LS & S & G & Ad \\
\hline 在来コン夘ート & $2 \pm 1$ & $2 \pm 1$ & 37.0 & 43.0 & 148 & 400 & 0 & 812 & 1154 & 2.40 \\
\hline 高流動コンクリート & $65 \pm 5$ & $2 \pm 1$ & 35.0 & 55.3 & 177 & 506 & 63 & 918 & 796 & 7.21 \\
\hline
\end{tabular}

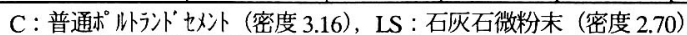

$\mathrm{S}$ : 葛生産石灭岩系砕砂 (密度 2.68 , 粗粒率 2.67), G : 玄武岩系砕石（密度:2.87, 粗粒率:6.74, 実積率:59.0\%, Gmax:20mm) $\mathrm{Ad}:$ 高性能減水剂（主成分はポ归怵 酒之配向术归一の複合体）

段 $: 2$ 回転/日年伤川

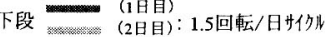

\begin{tabular}{|c|c|c|c|c|c|}
\hline 作業工程 \\
\hline \multirow{2}{*}{ 脱型 }
\end{tabular}

図-1 蒸気養生を施した場合の製造サイクルの例

が独自で機能の重要度を評価したものであるここ で，セグメント本体の耐久性能に関係する機能に着 目してみると, 表-1 中の(1)セグメントの防食および (2)トンネルの防水がそれにあたる。これらの内容に ついて詳細に見てみると, 二次覆工の機能は, 漏水, 塩害, 中性化, 硫化水素などによるコンクリートの 化学的腐食などにより，セグメントが劣化するのを 防ぐ，または遅延させるものと考えている 11). した がって，二次覆工を省略する場合には，トンネルの 用途や環境条件から定まる劣化要因を明確にし，そ れに対するセグメント本体の耐久性能を確保するこ とが重要となる. 一方, 耐火性能は道路トンネルに おいて重要な指標である. 二次覆工はトンネル内の 火災から一次覆工を防護する機能を有しており，耐 火性能が要求されるトンネルにおいてはこれを省略 する場合，セグメント本体に高い耐火性能を求める か，他の防護工を検討する必要がある.

\section{3. セグメントの製造に適用するコンクリートの基 本特性}

\section{（1）配合および養生条件}

本研究において，セグメントの製造に用いたコン クリートの示方配合を表-2に示す。これらの示方配 合は, 設計基準強度が $48 \mathrm{~N} / \mathrm{mm}^{2}$ の場合を想定したも のである.また, 高流動コンクリートは粉体系であ

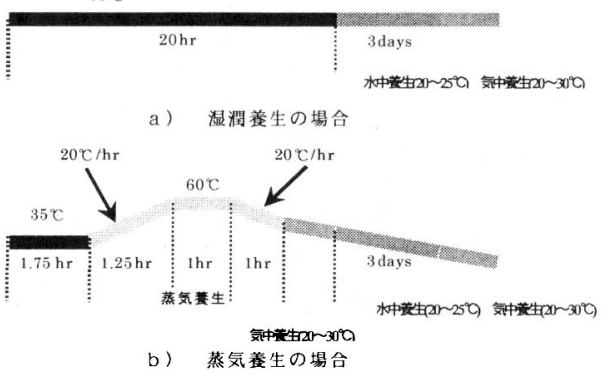

図-2 初期養生条件

り, セメントの一部を石灰石微粉末に置換して単位 セメント量を低減したものである 10).

コンクリート二次製品であるセグメントに適用す るコンクリートの初期強度の発現は，養生条件によ り異なり，それは製造に用いる型枠の使用効率に影 響を与える。すなわち，蒸気養生などを施してコン クリートの初期強度を早く発現させれば, コンクリ 一トの打設から脱型までの時間が短縮され，型枠の 使用効率が高まる．図-1 はこのことを考慮した 1 日 あたりの製造サイクルの一例を示したものである.

そこで，型枠の使用を 1.0 回転/日と想定した湿潤 養生とそれを $1.5 \sim 2.0$ 回転/日と想定した蒸気盖生と を養生条件として，まずは，コンクリートの強度発 現の特性を把握することとした。図-2 は，湿潤養生 と蒸気養生の養生温度を模式的に示したものである. なお，湿潤養生時および蒸気養生時の相対湿度は上 もに 95\%RH 以上とした。 


\section{（2）フレッシュ性状および圧縮強度}

在来コンクリートおよび高流動コンクリートのフ レッシュ性状を表-3 に示す．両者の塩化物イオン含 有量は, それぞれ $0.027 \mathrm{~kg} / \mathrm{m}^{3}$ および $0.036 \mathrm{~kg} / \mathrm{m}^{3}$ であ った.ここで, セメント協会の試験結果を参考に, 普通ポルトランドセメントおよび練混ぜ水に含まれ る塩化物イオンの最大值を算出する ${ }^{12)}$, , 在来コン クリートの場合および高流動コンクリートの場合で, それぞれ，0.06+0.03=0.09kg/ $\mathrm{m}^{3}$ および 0.076+0.035= $0.111 \mathrm{~kg} / \mathrm{m}^{3}$ となり, 試験から得られた塩化物イオン含 有量は両者ともに算出值の半分以下であった. また, これらの試験值を現状の示方書，指針類に示される コンクリートの品質基準 13),14)に照らしあわせても, その含有量は相当に小さいものであった．この結果 は，フレッシュな状態のコンクリート中にフリーデ ル氏塩が生成されたことが主な要因であると考えら れる 15)。フリーデル氏塩は炭酸化によって塩化物イ オンを解離することもあるが，十分な養生を施した 緻密なコンクリートであれば，コンクリート中に固 定化されるものと考えられる. したがって, 初期の 塩化物イオン含有量のみの観点からは, 在来コンク リートおよび高流動コンクリートの両者はともにそ の量が少なく，長期的にセグメントが劣化する場合 の主要因とはならないと考えられる.

次に, 高流動コンクリートについて，そのフレッ シュ性状が自己充てん性に与える影響について考察 する. セグメントの製造においては，継手部の金物 と鉄筋が錯綜することが多く, 極狭部にコンクリー 卜を充てんする必要が生じる. そこで, 高流動コン クリートのスランプフロー值および $\mathrm{V}$ 漏斗流下時間

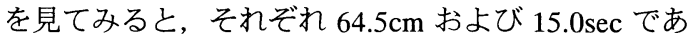
った. したがって，極狭部へのコンクリートの充て

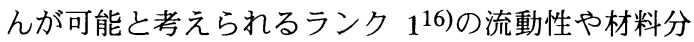
離抵抗性を確保しているものと判断した. なお，こ の配合により実際のセグメントを量産した結果から も，自己充てん性が保たれることを確認している.

次に, 在来コンクリートおよび高流動コンクリー 卜の圧縮強度とその発現特性について述べる. 図-3 はそれらの試験結果を示したものである. 材齢 28 日 における圧縮強度は, 養生条件に関わらず, 在来コ ンクリートよりも高流動コンクリートの方が大きく, また蒸気養生したものより湿潤養生したものの方が, 20〜30\%程度大きくなった.

一方, 前述したように, 型枠の使用効率を高める ためには，コンクリートを打設した後， 5 時間以内 で脱型できることが望ましい. また脱型時には，セ グメントそのものを 4 箇所ないしは 2 箇所で把持し て，その吊上げや方向転換などの作業を行う。この ことを考慮すると, 脱型時には $15 \mathrm{~N} / \mathrm{mm}^{2}$ 以上の圧縮
表-3 フレッシュコンクリートの性状

\begin{tabular}{ll|c|c}
\hline & & 在来コンクリート & 高流動コンクリート \\
\hline 壏化物イオン含有量 & $\left(\mathrm{kg} / \mathrm{m}^{3}\right)$ & 0.027 & 0.036 \\
\hline 空気量 & $(\%)$ & 2.2 & 2.3 \\
\hline コンクリート温度 & $(\mathrm{C})$ & 25.5 & 29.5 \\
\hline スランプ & $(\mathrm{cm})$ & 3.0 & - \\
\hline スランプフロー & $(\mathrm{cm})$ & - & 64.5 \\
\hline $\mathrm{V}$ 漏斗流下時間 & $(\mathrm{sec})$ & - & 15.0 \\
\hline
\end{tabular}

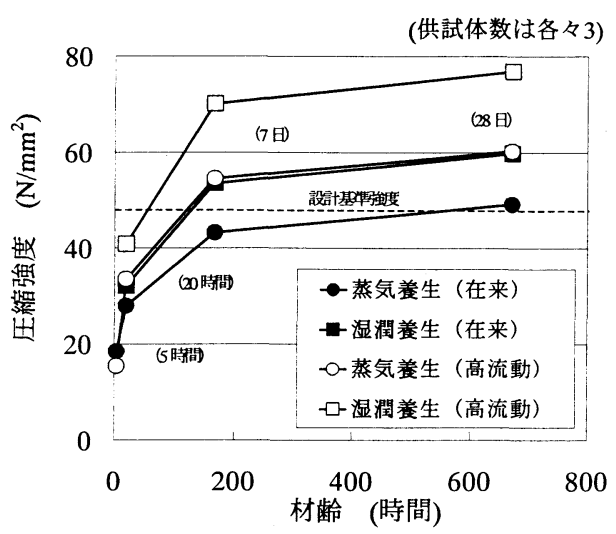

図-3材齢と圧縮強度

強度が求められる.この観点から, 在来コンクリー トおよび高流動コンクリートの材齢 5 時間の圧縮強 度を見てみると, 蒸気養生を施すことにより，それ ぞれ， $18.4 \mathrm{~N} / \mathrm{mm}^{2}$ および $15.4 \mathrm{~N} / \mathrm{mm}^{2}$ の圧縮強度が得 られたことがわかる.この結果は, 在来コンクリー トと比べて凝結遅延の傾向がある高流動コンクリー 卜(始発:5.5-6.0hr,終結:7.5-8.0hr)を用いても, 蒸気養 生を適切に施せば, $1.5 〜 2.0$ 回転/日サイクルのセグ メントの製造が可能であることを示唆している.

\section{4.セグメント用コンクリートの耐久性能およ び耐火性能}

\section{（1）耐久性能および耐火性能を評価するための指標 とその試験の概要}

セグメント用コンクリートの耐久性能を評価する ための指標およびその試験の概要を表-4に示す．前 述のとおり，満足すべき指標の設定は，トンネルの 用途に応じて異なる．本研究では，セグメントの製 造に用いるコンクリートの基本的な耐久性能を評価 することに主眼をおき，一般の RC 構造物に適用さ れるコンクリートの耐久性能の評価方法 17),18)を参 考にしてその指標を定めた．また，ひび割れなどの 欠陥は考慮していない。一方，粗骨材分布や耐火性 

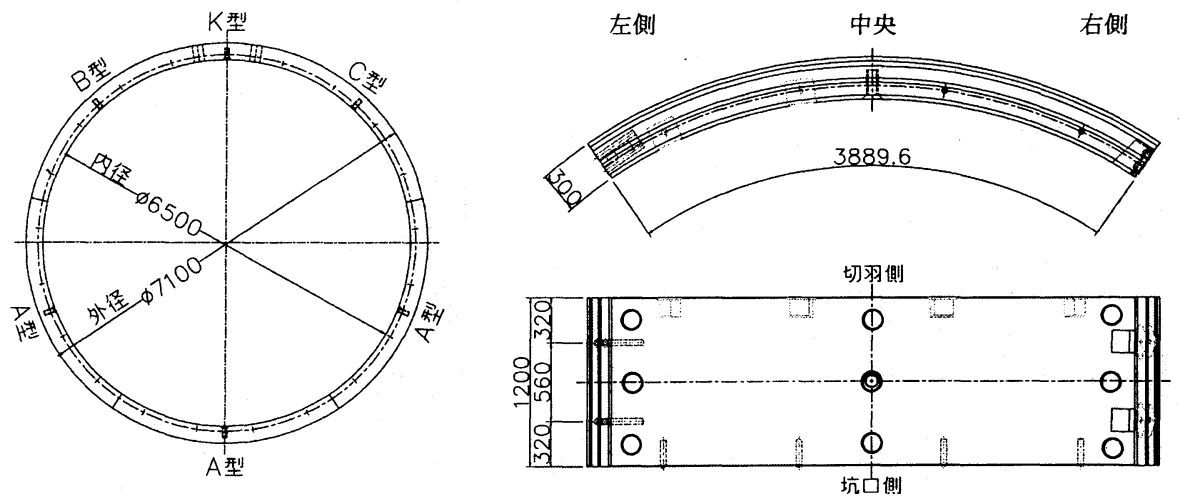

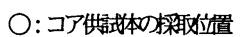

図-4＼cjkstart想定したセグメントリングおよび A 型セグメントの概要

表-4 而久性能の評価指標とその試験概要

\begin{tabular}{c|c|c}
\hline 評価指標 & 試験方法 & 測定項目等 \\
\hline 粗骨材分布 & 粗骨材面積率試験 & 粗骨材面積率 \\
\hline 透水性 & 透水試験 & 拡散係数, 透水係数 \\
\hline 塩分浸透性 & 促進塩分浸透試験 & 全塩分含有率 \\
\hline 乾燥収縮 & 長さ変化率試験 & 長さ変化率, 質量変化率 \\
\hline クリープ & クリープ試験 & クリープ係数 \\
\hline 中性化 & 促進中性化試験 & 中性化深さ \\
\hline 而火性 & 耐火試験 & 圧縮強度, 静弾性係数の保持率 \\
\hline
\end{tabular}

を確認する試験では, 対象とする構造部材の形状寸 法が試験結果に影響を与える. そこで, これらの試 験に用いる供試体の形状寸法は，セグメントリング 外径が $7.1 \mathrm{~m}$ のトンネルで, セグメント厚さが $300 \mathrm{~mm}$ の RC セグメント(図-4 参照)を想定して定めた. ま た, 各種の試験方法により, 供試体の前養生の方法 が異なる. 前養生の条件は, 各種の耐久性能の評価 に影響を与えると考えられる。ここでは，セグメン ト用コンクリートの基本的な耐久性能を把握するこ とを目的としているため, それぞれの試験方法に準 じて前養生の条件を設定した.

\section{（2）粗骨材分布}

コンクリート中の粗骨材分布の違いは, セグメン トの各部位のコンクリートの緻密性や強度のバラツ キに影響を与えると考えられる. とくに，コンクリ 一ト中に存在する微細な空隙や材料の不均一な分布 がコンクリートの水密性に影響を与えるとの報告も ある 19)。そこで，図-4 に示した A 型セグメントか ら採取したコア供試体およびセグメントと同一の養 生を施した管理供試体 (直径 $10 \mathrm{~cm}$, 高さ $20 \mathrm{~cm}$ ) の粗 骨材面積率をそれぞれ求め, 両者を比較することで 粗骨材分布の均一性を評価した. 粗骨材面積率の求 め方は次の方法によった 20).

管理供試体の場合は，まず図-5 中の(1)に示すよう
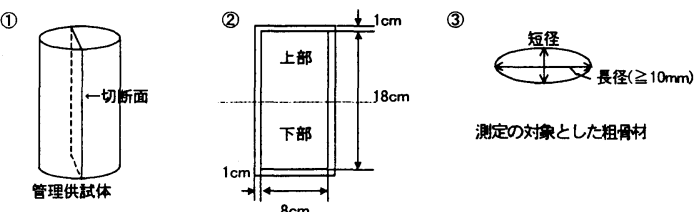

図-5 粗骨材面積の求め方

表-5 粗骨材面積率の算出結果 (供式体数は各々3)

\begin{tabular}{|c|c|c|c|c|c|c|}
\hline コンクリート種類 & \multicolumn{6}{|c|}{ 在来コンクリート } \\
\hline 供試体種類 & \multicolumn{5}{|c|}{ コア供試体 } & \multirow{2}{*}{ 管理供試体 } \\
\hline \multirow{3}{*}{ 粗骨材面積率(\%) } & & 左側 & 中央 & 右側 & 平均 & \\
\hline & 上部 & 27.2 & 26.2 & 30.3 & 27.9 & 27.4 \\
\hline & 下部 & 27.6 & 25.3 & 24.2 & 25.7 & 26.8 \\
\hline コンクリート種類 & \multicolumn{6}{|c|}{ 高流動コンクリート } \\
\hline 供試体種類 & \multicolumn{5}{|c|}{ コア供試体 } & \multirow{2}{*}{ 管理 } \\
\hline \multirow{3}{*}{ 粗骨材面積率(\%) } & & 左側 & 中央 & 右㑡 & 平均 & \\
\hline & 上部 & 25.9 & 24 & 25.9 & 25.3 & 25.2 \\
\hline & 下部 & 23.9 & 24.4 & 22.9 & 23.7 & 23.8 \\
\hline
\end{tabular}

に, 高さ方向に切断する. 次に, 切断面(幅 $10 \mathrm{~cm}$, 高さ $20 \mathrm{~cm}$ )を(2)に示すように上部(コア供試体の場合 のセグメント背面側)と下部(コア供試体の場合のセ グメント内面側)とに分け，上部と下部の幅 $8 \mathrm{~cm} \times$ 高 さ $9 \mathrm{~cm}$ をそれぞれの測定断面とする. 測定断面内で (3)に示す長径 $10 \mathrm{~mm}$ 以上の粗骨材の総面積を測定す る. 粗骨材面積率は測定面積に対する粗骨材の総面 積の割合とし，式(1)で表すものとする.

$$
\begin{aligned}
\text { 粗骨材面積率 }(\%)= & (\text { 長径 } 10 \mathrm{~mm} \text { 以上の } \text { 粗骨材の } \text { 総面積 }) \text { (貺定面積 }) \times 100
\end{aligned}
$$

コア供試体の場合は，製作したセグメントの中央 部と左右の端部から, 直径 $10 \mathrm{~cm}$ のコアを採取し, 管 理供試体の場合と同様に粗骨材面積率を求める.

以上の方法により求めた粗骨材面積率の結果を表 -5 に示す．この結果から，在来コンクリートおよび 高流動コンクリートはともに, セグメントの各部位 
表-6 透水試験の結果

\begin{tabular}{|c|c|c|c|c|c|c|c|c|c|c|c|c|}
\hline \multirow{2}{*}{ 種類 } & \multirow{2}{*}{$\begin{array}{c}\begin{array}{c}\text { 水压 } \\
\left(\mathrm{kgf} / \mathrm{cm}^{2}\right)\end{array}\end{array}$} & \multirow{2}{*}{\begin{tabular}{|c|} 
透水時間 \\
$(\mathrm{sec})$ \\
\end{tabular}} & \multicolumn{3}{|c|}{ 浸透深さ $(\mathrm{cm})$} & \multicolumn{3}{|c|}{ 拡散係数 $\left(\times 10^{-4} \mathrm{~cm}^{2} / \mathrm{sec}\right)$} & \multirow{2}{*}{$\begin{array}{c}\text { 体積弾性率 } \\
\left(\times 10^{5} \mathrm{kgf} / \mathrm{cm}^{2}\right)\end{array}$} & \multicolumn{3}{|c|}{ 透水係数 $(\mathrm{cm} / \mathrm{sec})$} \\
\hline & & & 最大 & $\begin{array}{l}\text { 最小 } \\
\end{array}$ & 平均 & 最大 & 最小 & 平均 & & 最大 & $\begin{array}{l}\text { 最小 } \\
\end{array}$ & 平均 \\
\hline \multirow{3}{*}{ 在 来 } & \multirow{3}{*}{5} & 1220390 & 5.4 & 0.0 & 2.5 & 29.50 & 0.00 & 6.33 & 8.92 & \multirow{4}{*}{$2.34 \times 10^{-12}$} & \multirow{4}{*}{$6.72 \times 10^{-15}$} & \multirow{4}{*}{$3.72 \times 10^{-13}$} \\
\hline & & 1225740 & 4.7 & 0.0 & 0.8 & 22.30 & 0.00 & 0.65 & 7.50 & & & \\
\hline & & 1221590 & 2.1 & 0.4 & 1.4 & 4.46 & 0.16 & 1.98 & 7.63 & & & \\
\hline 在来 (平均) & - & - & \multicolumn{3}{|c|}{ - } & 18.80 & 0.05 & 2.99 & 8.02 & & & \\
\hline \multirow{3}{*}{ 高流動 } & \multirow{3}{*}{5} & 1223580 & 1.4 & 0.0 & 0.6 & 1.98 & 0.00 & 0.36 & 8.01 & \multirow{4}{*}{$2.85 \times 10^{-13}$} & \multirow{4}{*}{$1.77 \times 10^{-15}$} & \multirow{4}{*}{$9.56 \times 10^{-14}$} \\
\hline & & 1220390 & 1.6 & 0.0 & 0.9 & 2.59 & 0.00 & 0.82 & 7.19 & & & \\
\hline & & 1225740 & 1.4 & 0.2 & 1.0 & 1.98 & 0.04 & 1.01 & 7.70 & & & \\
\hline 高流動 (平均) & - & - & \multicolumn{3}{|c|}{ - } & 2.18 & 0.01 & 0.73 & 7.63 & & & \\
\hline
\end{tabular}

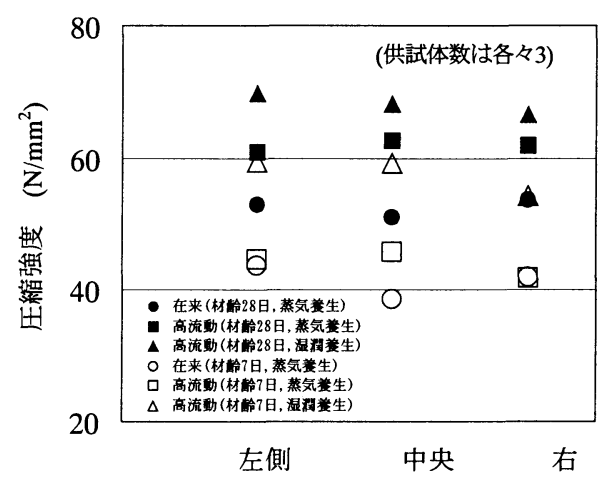

図-6 セグメントの各部位の圧縮強度

に, 粗骨材がほぼ均一に配されていると考えられる.

次に, 粗骨材分布の違いが圧縮強度に与える影響 を把握するために, 粗骨材分布を調べた部位の近傍 からコア供試体を採取して材齢 7 日および材齢 28 日 の圧縮強度を調べた. その結果が図-6である. 型枠 内に打設されたコンクリートの圧縮強度はほぼ均一 であった. 以上の結果から, コンクリート中の粗骨 材はほぼ均一に分布していると判断した.

\section{（3）透水性}

セグメント用コンクリートの透水性は，コンクリ 一ト中の水の拡散係数および透水係数を求めて評価 した. 試験に用いた供試体は，28日間の標準水中養 生を施した円柱供試体(直径 $15 \mathrm{~cm}$, 高さ $30 \mathrm{~cm}$ )を, 高 さ方向で 3 分割し, 中央の $10 \mathrm{~cm}$ 部分を採取したもの とした. 次に, この供試体を恒温恒湿室(温度 $20^{\circ} \mathrm{C}$, 相対湿度 $60 \% \mathrm{RH}$ )内で 28 日間静置させた. 試験はイ ンプット法 21)による透水試験装置を用いて約 14 日 間, 供試体の下面から $5 \mathrm{kgf} / \mathrm{cm}^{2}$ の水圧下で試験水を 浸透させ, その浸透深さを測定して, 拡散係数や透 水係数を求めることとした 22 .

試験から得られた透水時間と試験水の浸透深さと の関係を, 式(2)および式(3)に代入して拡散係数およ び透水係数を求めた. 式(2)はコンクリート中の水の 流れを拡散流としてFourierの熱伝導方程式の温度を 水圧に置き換えて得られる式 19)であり, 式(3)は式(2) から一方向の流れを考慮して得られるものである ${ }^{19) .}$

\author{
$\beta_{i}^{2}=\alpha \frac{D^{2}}{4 \cdot t \cdot \xi^{2}}$$$
\mathrm{K}=\frac{\beta_{\mathrm{i}}^{2} \cdot \rho}{\mathrm{E}_{\mathrm{v}}}
$$ \\ ここに, \\ $\beta_{\mathrm{i}}^{2}:$ 拡散係数 $\left(\mathrm{cm}^{2} / \mathrm{sec}\right)$ \\ $\alpha:$ 水圧を加えた時間に関する係数 $\left(=\mathrm{t}^{3 / 7}\right)$ \\ $\mathrm{D}:$ 浸透深さ $(\mathrm{cm})$ \\ $\mathrm{t}$ : 透水時間 $(\mathrm{sec})$ \\ $\xi^{2}:$ 透水定数 $(=0.82176038)$ \\ $\mathrm{K}$ : 透水係数 $(\mathrm{cm} / \mathrm{sec})$ \\ $\rho:$ 水の密度 $\left(20^{\circ} \mathrm{C},=0.0009982 \mathrm{~kg} / \mathrm{cm}^{3}\right)$ \\ $\mathrm{E}_{\mathrm{v}}$ : 体積弾性率 $\left(\mathrm{kgf} / \mathrm{cm}^{2}\right)$ \\ (別途,一軸圧縮試験から得た 応力と \\ 体積ひずみの関 係から求めた值 )
}

試験の結果を示したのが, 表-6 である. 拡散係数 および透水係数の值をみると, 在来コンクリートお よび高流動コンクリートのそれらはともに相当に小 さい.このことは，これまでに言われている 19),23) ように, 水セメント比が小さいことが主な要因と考 えられる. また，セグメント用コンクリートに用い ている粗骨材の最大寸法が $20 \mathrm{~mm}$ と小さいことも拡 散係数や透水係数が小さくなる要因である. なお, 高流動コンクリートの配合は富配合ではあるが, 透 水係数が大きくなる傾向は認められない. したがっ て, 水密性の観点からは, 在来コンクリートおよび 高流動コンクリートの両者はともに高い性能を有し ている.

\section{（4）塩分浸透性}

コンクリート中への塩水の浸透性は, 水道水より も低い．これは塩類とセメントペースト硬化体との 反応生成物がコンクリート中の空隙を充てんするた めと考えられている 22).このことのみを考えると， コンクリート中の透水性が低ければ, 塩分浸透性は より低いものと考えられる. しかし一方で, 塩水中 の塩化物イオンは, 目視から判断される塩水の湿潤 面よりも先行してコンクリート中に浸透する場合が あることも考えられる. そこで，セグメント用コン 
クリートの透水性を確認する試験とは別に，コンク リート中への塩分の浸透性を確認する試験を行った. 供試体の形状寸法は $10 \times 10 \times 40 \mathrm{~cm}$ の角柱である. 供試体の前養生は，28 日間の標準水中養生を施した 後に, 恒温恒湿室(温度 $20^{\circ} \mathrm{C}$, 相対湿度 $60 \% \mathrm{RH}$ )内で 28 日間の静置とした.

塩分浸透試験は供試体の一面 $(10 \times 40 \mathrm{~cm})$ 以外の面 にエポキシ樹脂を塗布した後, 恒温恒湿室(温度 $20^{\circ} \mathrm{C}$, 相対湿度 $60 \% \mathrm{RH}$ )内で塩分濃度 $3 \%$ の人工海水に供試 体を浸せきさせるのと乾燥させるのとを繰り返す(3 日間の浸せきと 4 日間の乾燥を 1 サイクルとして, 26 サイクル)促進試験 24) とし, 供試体の浸せき前, 3 ケ月後, 6 ケ月後において, 供試体の表面から $10 \pm$ $5 \mathrm{~mm}$ および $25 \pm 5 \mathrm{~mm}$ の 2 箇所の全塩分を測定 25 して 行った．全塩分を測定した $10 \pm 5 \mathrm{~mm}$ の位置は，セグ メントを製作する上で最も小さい鉄筋かぶり 26)を想 定したものであり, $25 \pm 5 \mathrm{~mm}$ の位置は, 二次覆工を 省略する際に多用されているセグメントの鉄筋かぶ り 27)を想定したものである.

試験結果を表-7 および図-7 に示す. 在来コンクリ ートにおいて, かぶりが $10 \mathrm{~mm}$ の位置の促進 6 ケ月 後をみると, 全塩分含有率が $0.03 \%$ となっているも のの, それ以外では, 全塩分含有率が $0.01 \%$ 未満で あった.この結果から, 基本的に鉄筋腐食に大きく 影響する塩分の浸透性は低く, 在来コンクリートお よび高流動コンクリートの両者はともに, 鉄筋の腐 食速度が一般のコンクリートに比較して小さいと考 えられる 28)。 また，二次覆工を省略する場合には， $25 \mathrm{~mm}$ 以上のかぶりをとることにより，それが $10 \mathrm{~mm}$ の場合に比べて塩分浸透の影響が小さくなる.

一方，鉄筋腐食は，塩分浸透性のみならず，コン クリートの中性化速度とも強く関連する. 両者の総 括的な耐久性能の考察は, (7) 中性化で詳述する.

\section{（5）乾燥収縮}

コンクリートに生じるひび割れの発生原因は種々 に考えられるが, 中でもコンクリートの乾燥収縮は, ひび割れ発生とその拡大に及ぼす影響が大きい。一 般に乾燥収縮は，コンクリート中のセメントペース 卜量や単位水量の影響を受ける. そこで現行の規準 類では, 単位水量を極力低減し, 高性能AE減水剂を 用いたコンクリートの場合は, 単位水量を $175 \mathrm{~kg} / \mathrm{m}^{3}$ 以下とすることを原則として定めている 29). 一方, 本研究で対象としている粉体系の高流動コンクリー 卜の場合, 単位水量が $177 \mathrm{~kg} / \mathrm{m}^{3}$ とこの規定值より多 く, また, モルタル容積率が $0.53 \mathrm{~m}^{3} / \mathrm{m}^{3}$ であり, セメ ントペースト量も多い.このため, 乾燥収縮量を把 握することがとくに重要と考えた. さらに, 乾燥収 縮量は, 初期養生の条件の影響を顕著に受けると考
表-7 塩分浸透試験における全塩分の測定結果

\begin{tabular}{|c|c|c|c|c|c|}
\hline \multicolumn{2}{|c|}{ コンクリート種類 } & \multicolumn{2}{|c|}{ 在来コンクリート } & \multicolumn{2}{|c|}{ 高流動コンクリート } \\
\hline \multicolumn{2}{|c|}{ 試駼指標 } & $\begin{array}{c}\text { 表偭からの深さ } \\
10 \mathrm{~mm}\end{array}$ & $\begin{array}{c}\text { 表面からの深さ } \\
25 \mathrm{~mm}\end{array}$ & $\begin{array}{c}\text { 表面力5の深さ } \\
10 \mathrm{~mm}\end{array}$ & $\begin{array}{c}\text { 表面からの梁さ } \\
25 \mathrm{~mm}\end{array}$ \\
\hline \multirow{3}{*}{$\begin{array}{c}\text { 全塩分含有率 } \\
\text { (\%) }\end{array}$} & 初期 & 0.004 & 0.004 & 0.004 & 0.004 \\
\hline & 促進了个月後 & 0.006 & 0.003 & 0.004 & 0.004 \\
\hline & 促隹的月後 & 0.031 & 0.003 & 0.006 & 0.003 \\
\hline
\end{tabular}

注）供試体数は土各々3

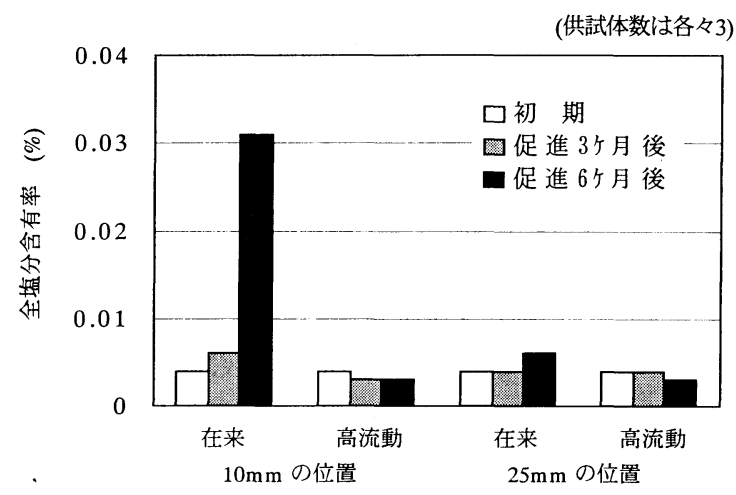

図-7 全塩分の測定結果

え，セグメントの製造と同じ初期養生の条件(湿潤養 生と蒸気盖生)で供試体を作製して試験した. 乾燥収 縮量は図-2に示したセグメントの製造と同じ初期盖 生を施した後に, 材龄が 28 日となるまで標準水中養 生を行い, その後に供試体を恒温恒湿室(温度 $20^{\circ} \mathrm{C}$, 相対湿度 $60 \% \mathrm{RH}$ )内で乾燥させながら, 経時的に乾 燥収縮量と質量減少量とを測定する 30 )ことにより把 握した.

図-8a)および図-8b)はそれらの結果である. 乾燥 収縮の大きさとひび割れ発生の関係は必ずしも定量 化されてはいないが，一般に硬化乾燥収縮を拘束す ることによるひび割れの発生条件は，式(4)のように 考えられている31).

$$
\begin{aligned}
\text { 乾燥収縮ひずみ } \geqq \text { 弾性ひずみ }+ \text { 粘弾性ひずみ } \\
+ \text { 拘束緩和ひずみ }
\end{aligned}
$$

ここで, コンクリートの弾性ひずみは $150 \times 10^{-6}$ 程 度，粘弾性ひずみと拘束緩和ひずみとを合わせたも のは, およそ400〜 $500 \times 10^{-6}$ となるので, ひび割れが 発生しないための乾燥収縮ひずみの限界值は600〜 $700 \times 10^{-6}$ 以下と考えられる31)。このことを考虑して 図-8a)の乾燥収縮量を見てみると，在来コンクリー トに比べて, 高流動コンクリートの方が若干多いも のの，6ケ月が経過した段階では，すべてのケースで 乾燥収縮量が $600 \times 10^{-6}$ を回っていた．また，12ケ 月が経過した段階でも，乾燥収縮量は $700 \times 10^{-6}$ 以下 となっていた. また, 初期養生の違いによる乾燥収 


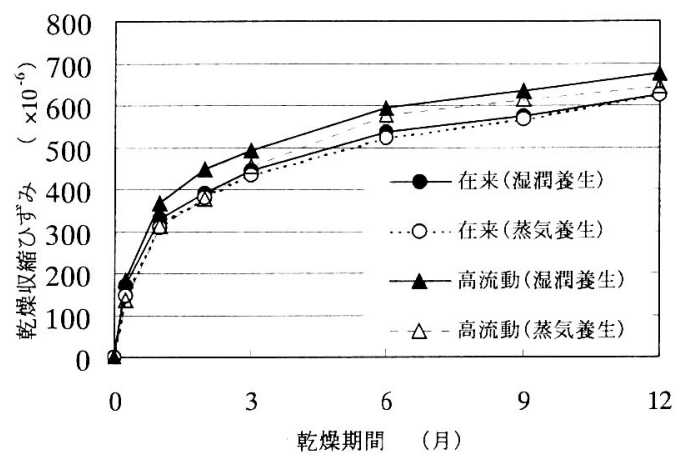

図-8a）乾燥収縮試験の結果（乾燥収縮ひずみ）

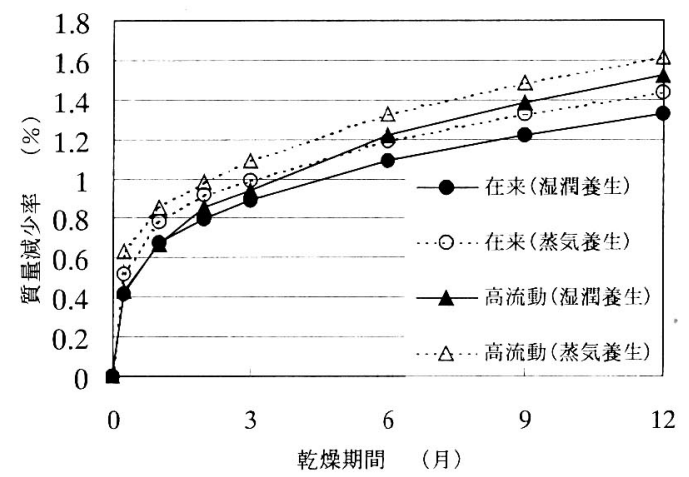

図-8b）乾燥収縮試験の結果(質量減少率)

縮量への影響は，図-8b)に示した質量減少率に若干 の差異が認められるものの, その影響は小さかった. したがって，在来コンクリートおよび高流動コンク リートの両者はともに乾燥収縮による耐久性能の低 下はほとんどないものと考えられる。

(6) クリープ

セグメント用コンクリートは，一般のコンクリー トに比ベてセメントペース卜量が多く, クリープも 大きくなる可能性がある. そこで, クリープ試験を 行い, クリープ特性を把握した。試験方法は種々に あるが，ここでは写真-1 に示すJIS原案 32)を採用し た.

供試体は円柱供試体（直径 $10 \mathrm{~cm}$, 高さ $20 \mathrm{~cm}$ ) であり, 試験開始までの供試体の前養生は, 標準水中養生を 28 日間とした. クリープ試験時の載荷応力は, 現状 のセグメントの設計が許容応力度設計法によること を考慮し, 試験開始材齢 $(28$ 日)の圧縮強度の $1 / 3$ とし た．在来コンクリートおよび高流動コンクリートの それらの值はそれぞれ, $19.9 \mathrm{~N} / \mathrm{mm}^{2}$ および $24.5 \mathrm{~N} / \mathrm{mm}^{2}$ である.

試験の結果を図-9 に示す．なお，載荷期間 12 ケ 月時のクリープひずみは, 在来コンクリートおよび 高流動コンクリートで，それぞれ $695 \times 10^{-6}$ および $1008 \times 10^{-6}$ であった.

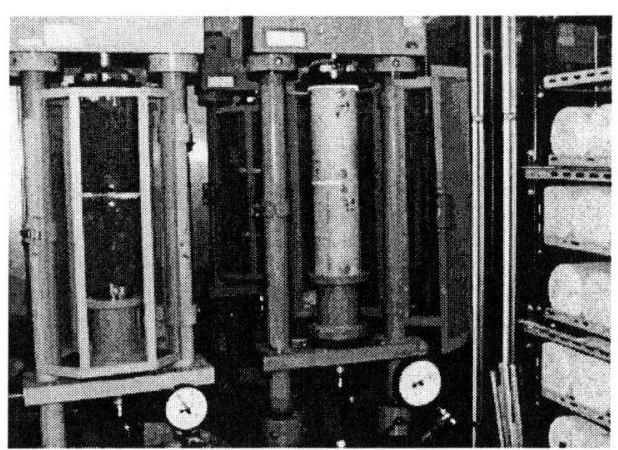

写真-1 クリープ試験の状況

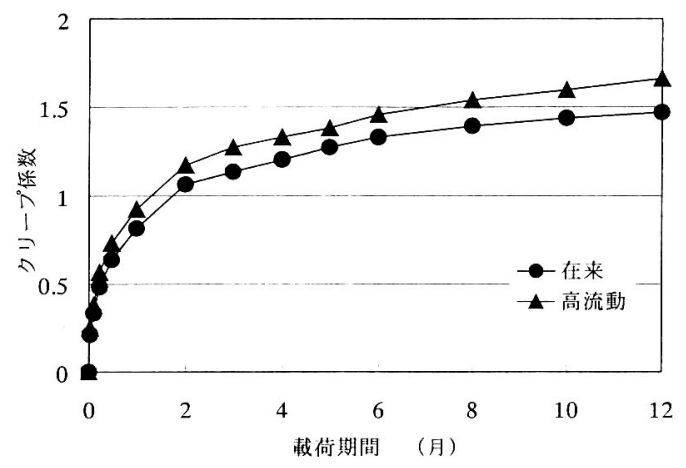

図-9 クリープ試験の結果

クリープ係数は, その值のみから直接的に耐久性 能を評価するものではない. したがって, 在来コン クリートおよび高流動コンクリートの基本的なクリ 一プ特性を把握することとしたものである.この結 果から両者のクリープ係数はともに 1.5 程度であり, 過大なクリープが生じるおそれがない．

\section{（7）中性化}

コンクリート表面からの中性化は，鉄筋の腐食に 影響を及ぼす，そこで，セグメント用コンクリート の促進中性化試験を行い, 中性化に対する抵抗性を 調べた．試験に用いた供試体は $10 \times 10 \times 40 \mathrm{~cm}$ の角柱 供試体である，供試体の前養生は，28 日間の標準水 中養生を施した後に, 恒温恒湿室(温度 $20^{\circ} \mathrm{C}$, 湿度 60\%)内で 28 日間の静置とした. 試験方法は日本建築 学会の方法に準じた ${ }^{33)}$. 写真-2 は中性化深さを測定 している状況である.なお, 促進中性化時の炭酸ガ ス濃度は $5 \pm 0.2 \%$ である.

図-10は試験結果であり, 促進中性化期間と中性化 深さの関係を示したものである，この結果から，在 来コンクリートおよび高流動コンクリートは26週後 において, 中性化深さが $8 \mathrm{~mm}$ 以下であり, 中性化速 度は小さいもの34)と考えられる. しかし，コンクリ 一トの中性化は，その速度だけで耐久性能を評価で きるものではないと考えられる，そこで，先の透水 
試験および促進塩分浸透試験の結果もあわせて，考 察を加える.

中性化の進行は,コンクリート中の炭酸ガス (二酸 化炭素など)の拡散速度の大きさによって定まる。こ のような気体の拡散はコンクリート中の水分で閉塞 されていない空隙を介して起こる．これは液相にお ける抬散が気相に比べて無視し得るほど小さいため, 水分の逸散した空隙のみで炭酸ガスの拡散が起こる と見なすことができるためである 35)。したがって， コンクリート中の含水状態の程度が炭酸ガスの拡散 に大きな影響を与える.

一方, 細孔空隙に侵入した二酸化炭素は細孔中の 水分に溶解し, 炭酸イオンもしくは炭酸水素イオン になり，これらのイオンとセメント水和物との反応 が炭酸化反応である．このため，炭酸化反応には水 分が必要である．これらのことを考慮すると，中性 化速度は二酸化炭素の侵入・拡散と炭酸化反灾の両 者が起きる中程度の湿度 $(40 \sim 60 \% \mathrm{RH})$ の状態で最大 となる 36)。したがって，コンクリートの中性化に対 する抵抗性の評価は, 単に中性化速度のみならず, 水の拡散性や透水性をも考慮する必要があると考え られる，そこで，先の透水試験の結果を見ると，在 来コンクリートおよび高流動コンクリートの両者の 拡散係数や透水係数はともに小さな值である.

次に, 中性化速度が影響する鉄筋腐食の可能性に ついて考察する.フェノールフタレイン法による中 性化深さの判定では, pH8.2 10 以下の未着色部分が 中性化と判定される。一方, 鉄筋の腐食はpH11 以下 でも開始する．これは中性化残り(鉄筋のかぶり厚さ と中性化深さの差)の影響を受けるものであり,コン クリート中の塩分の有無により, その程度は異なる. 中性化残りは塩分を含まない場合で約 $8 \mathrm{~mm}$, 塩分を 含む場合で約 $20 \mathrm{~mm}$ とされている 37 )。このことを考 慮すると, セグメントの内部環境および外部環境か らの塩化物イオンの侵入が予測される場合には, 中 性化速度のみならず，中性化残りも考慮して鉄筋か ぶりを設定することが重要である，したがって，先 の促進塩分浸透試験の結果をあわせ考えると，鉄筋 腐食の観点から耐久性能を確保するためには，外部 からの塩化物イオンの侵入やフリーデル氏塩の分解 が予測される場合には，鉄筋かぶりを $8+20=28 \mathrm{~mm}$ 上，それらが予測されない場合には，鉄筋かぶりを 8+8=16mm以上とすることが望ましい.

\section{（8）耐火性}

コンクリートの熱膨張係数, 比熱, 熱伝導率およ び熱拡散係数などの熱的性質は, 水セメント比や材 齢などの影響も受けるが，主に骨材の種類および単 位量に影響されると考えられている。一般にコンク

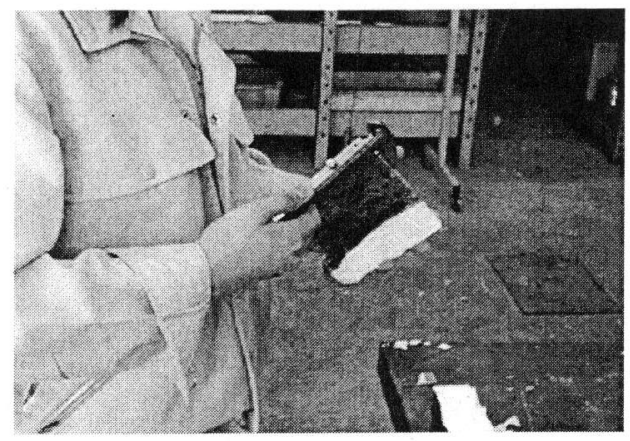

写真-2 促進中性化試験の状況

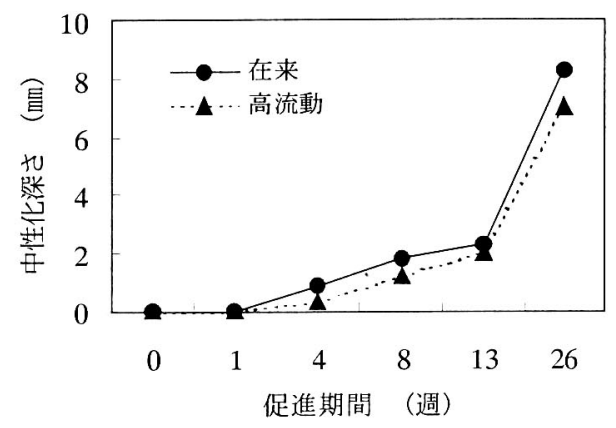

図-10 促進中性化試験の結果

リートの圧縮強度および静弾性係数は, $500^{\circ} \mathrm{C}$ に加熱 されると, 常温時のそれぞれ 60\%および 10〜20\%程 度になる 38)。しかしながら, 高強度となるセグメン ト用コンクリートの耐火性能を評価する上で, 既往 のデータが十分であるとは言い難い 39)。 そこで, 而 火試験を行い, 耐火性能を確認したものである.

試験に用いた供試体は，図-4に示したセグメント を模擬したものであり，1000×900×300mmのRC板 とした (図-11 参照). 鉄筋量および配筋は実際のセ グメントと同じとした。 また，大口径のシールドト ンネルを模擬していることから, 配力筋の純かぶり は約 $45 \mathrm{~mm}$ とした. なお, 供試体の初期養生はセグ メントの製作と同じ条件とし, 材齢 28 日までは気中 養生 $\left(28^{\circ} \mathrm{C}\right)$ を施した.

而火試験は，わが国のシールド工法による道路卜 ンネルの特徵や既往の実績を考慮して, JIS A 130440) に準拠し，無載荷の加熱試験とした．写真-3〜写真 -5 は試験の状況を示したものである. 加熱時間はト ンネル内で火災が発生し, 消火されるまでの時間を 想定して 4 時間とした. コンクリートの耐火性能は, 加熱処理と注水処理を施した供試体およびそれらを 施さない供試体から，それぞれコア(直径 $10 \mathrm{~cm} \times$ 高 さ $20 \mathrm{~cm}$ )を採取し，それを用いた圧縮強度試験およ び静弾性係数試験の結果から評価した.

図-12 および図-13 は加熱時の温度曲線およびコ ンクリート温度を示したものである. 加熱側となる 


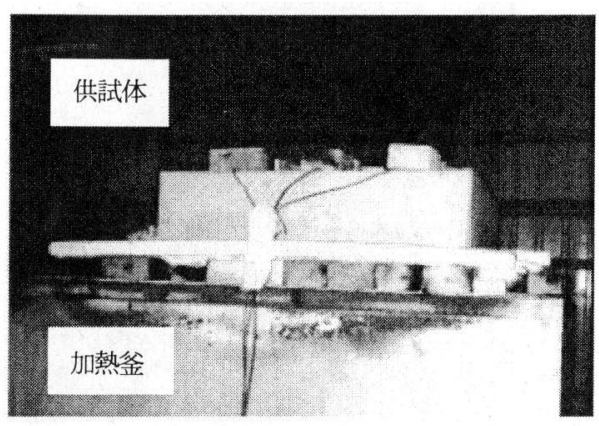

写真-3 加熱状況 (無載荷)

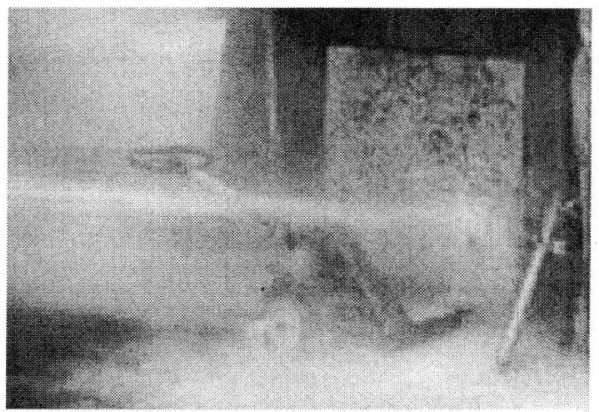

写真-4 火災消火を模擬した注水状況

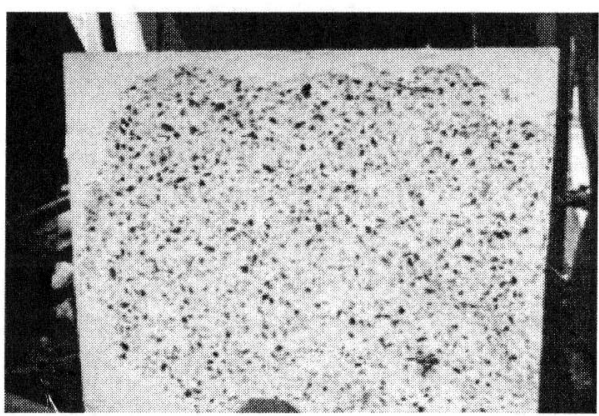

写真-5 加熱, 注水後の供試体表面の状況

コンクリート表面の温度は, 4 時間で $1100^{\circ} \mathrm{Cまで上}$ 昇し，ほぼ定常状態に近づいていた.

一方, コンクリート表面から $150 \mathrm{~mm}$ 内側に入った 中央部の温度は $200^{\circ} \mathrm{C}$ 程度となっており, この傾向 は, 在来コンクリートおよび高流動コンクリートの 両者はともに同じであった。しかしながら, その温 度上昇速度は高流動コンクリートの方が若干緩やか な勾配を示していた。これはコンクリート中の含水 量の影響およでセグメント表面の組織構造 41)の影響 なよ゙により，在来コンクリートと高流動コンクリー トの蒸発潜熱に違いが生じたためと考えられる。な お, 使用した骨材の吸水率は平均 $2 \%$ 程度であり, 初 期のコンクリート中の含水量は在来コンクリートの 場合で $187 \mathrm{~kg} / \mathrm{m}^{3}$, 高流動コンクリートの場合で $212 \mathrm{~kg} / \mathrm{m}^{3}$ であった.

加熱の初期段階ではコンクリート表面の温度が

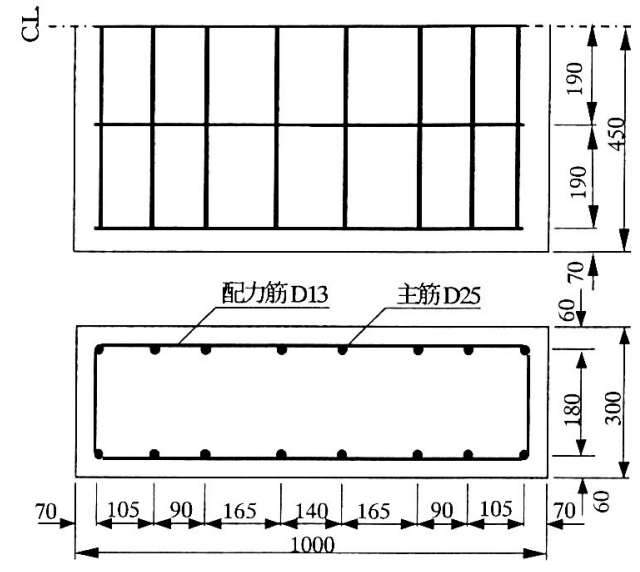

図-11 供試体の形状寸法と配筋

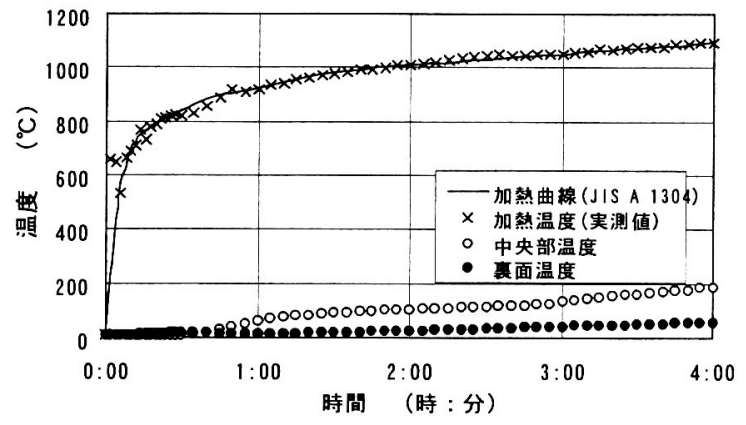

図-12 加熱状況（在来コンクリート）

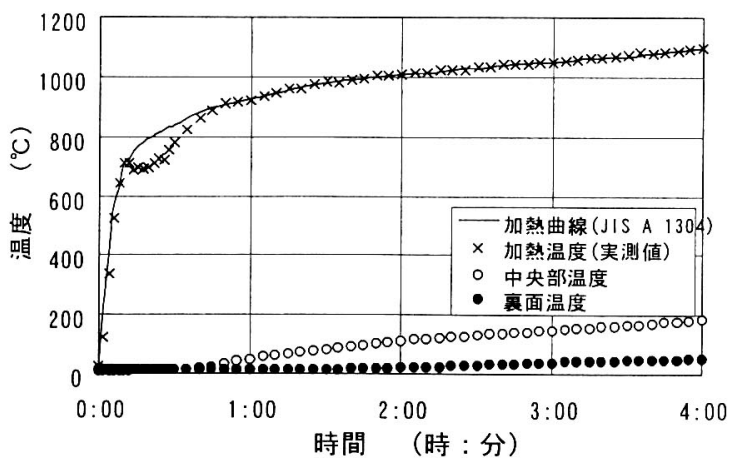

図-13 加熱状況（高流動コンクリート）

$900^{\circ} \mathrm{C}$ 近くまで急激に上昇するため, 在来コンクリー トおよび高流動コンクリートの両者で, 鉄筋のかぶ り部のコンクリートがはく離する現象が確認された (爆裂音により確認)。また, 注水時には急激にコン クリート表面が冷却されるため, 温度上昇時と同様 に，かぶり部のコンクリートが爆裂してはく離する 現象がみられた。このかぶり部のコンクリートのは く離面積は, 在来コンクリートの場合よりも高流動 コンクリートの場合の方が若干多く，はく離した深 さはそれぞれ，約 $30 \mathrm{~mm}$ と約 $40 \mathrm{~mm}$ であった．このこ とは，コンクリートの組織が緻密な高強度コンクリ 一トの特徵であり, 従来から報告されている結果 39) 


\section{表-8 耐火試験の結果}

\begin{tabular}{|c|c|c|c|c|c|c|c|c|}
\hline コンクリート種類 & \multicolumn{4}{|c|}{ 在来コンクリート } & \multicolumn{4}{|c|}{ 高流動ロンクリート } \\
\hline \multirow{3}{*}{ 話駼指摽 } & \multicolumn{2}{|c|}{ 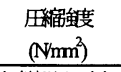 } & \multicolumn{2}{|c|}{ 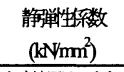 } & \multicolumn{2}{|c|}{$\begin{array}{l}\text { 因綰蛅度 } \\
\left(\mathrm{N}^{2} \mathrm{~mm}^{2}\right)\end{array}$} & \multicolumn{2}{|c|}{$\begin{array}{c}\text { 静弾生经数 } \\
\left(\mathrm{N} / \mathrm{mm}^{2}\right)\end{array}$} \\
\hline & 加堆姆 & 貯有無 & 加薙奶 & 跙有無 & 加笅处 & 有無 & 加熱処 & 有無 \\
\hline & $\begin{array}{ll}\text { 無 } \\
\end{array}$ & 有 & $\begin{array}{ll}\text { 無 } \\
\end{array}$ & 有 & $\begin{array}{l}\text { 無 } \\
\end{array}$ & 有 & $\begin{array}{l}\text { 無 } \\
\end{array}$ & 有 \\
\hline 平均檤 ${ }^{\prime \prime}$ & 522 & 427 & 37.6 & 33.7 & 69.4 & 65.6 & 38.9 & 38.6 \\
\hline 残存率 (\%) & - & 81.6 & & 89.6 & & 94.6 & & 99.4 \\
\hline
\end{tabular}

とも一致する. なお, 加熱処理および注水処理を施 した供試体から採取したコアを観察したところ，在 来コンクリートおよび高流動コンクリートの両者は ともに加熱した表面から約 $10 \mathrm{~cm}$ 深さまで黄色く 変色していた.

次に, コアの上下の端部を成形し，その中央部か ら作製した供試体（直径 $10 \mathrm{~cm} \times$ 高さ $20 \mathrm{~cm}$ ) を用いて 圧縮強度試験および静弾性係数試験を行った. 表-8 はそれらの結果を示したものである．加熱処理と注 水処理を施した後の圧縮強度の残存率をみると, 在 来コンクリートの場合で $81.6 \%$, また高流動コンク リートの場合で $94.6 \%$ となっており，両者はともに 圧縮強度の低下が少なかった. 前述のとおり, $500^{\circ} \mathrm{C}$ 程度まで加熱されると圧縮強度は半分程度に低下す ると言われているが, 加熱試験の状況から，コンク リート内部の温度は $200^{\circ} \mathrm{C}$ 程度までしか上昇しなか ったため, 圧縮強度の残存率が大きくなったものと 考えられる.

静弾性係数の残存率をみると, 在来コンクリート の場合で $89.6 \%$, 高流動コンクリートの場合で $99.4 \%$ であり, 圧縮強度の残存率とほぼ同様な結果を得た。

すでに述べたように, 本試験ではわが国のシール ド工法による道路トンネルは比較的長大かつ大断面 であるという特徵, および東京湾横断道路建設にお ける可とうセグメントの設計基準等を考慮して，す なわちトンネル火災が消火されるまでの時間を 4 時 間と想定して, 耐火試験の加熱曲線にJIS A 1304 を用 いた．この曲線は，RABT曲線 42)やRWS曲線 43) と比 較して最高温度は低いものの加熱時間が長いことに その特徵がある. 本試験結果から,このような長時 間に及ぶ加熱下においても，在来コンクリートおよ び高流動コンクリートはともに, かぶり部のコンク リートの損傷のみであり, 鉄筋位置より内側のコン クリートは約 8 割以上の残存強度を有していること がわかる．筆者らは，トンネル火災のように発生確 率と規模が不明確な事象については, トンネルの耐 荷力に直接影響のないかぶりまでの損傷を許容する のが合理的と考えている. したがって，トンネル覆 工の健全性は概ね保たれていると考えられる.

\section{5. まとめ}

本研究では，シールド工事用セグメントの製造に 適用するコンクリートとして, 在来(硬練り)コンク リートと高流動コンクリートとを取り上げ，これら の基本的な耐久性能および耐火性能を，各種の試験 から評価し，検討を加えた．得られた主な結論を挙 げると以下のとおりである.

(1) フレッシュ状態における塩化物イオン含有量 を調べた結果, 在来コンクリートおよび高流 動コンクリートの両者はともにその量が少な く，長期的にセグメントが劣化する場合の主 要因とはならないと考えられる.

(2) 在来コンクリートおよび高流動コンクリート の両者はともに, 水の拡散係数および透水係 数が小さい．これは，主に使用する粗骨材の 最大寸法が $20 \mathrm{~mm}$ と小さく, また両者の水セメ ント比がともに小さいことに起因するものと 考えられる.

(3) 乾燥収縮試験の結果, 在来コンクリートおよ び高流動コンクリートの両者の乾燥収縮量は ともに 12 ケ月が経過した段階で $700 \times 10^{-6}$ 以 下であり，ひび割れの発生や拡大に対して乾 燥収縮がとくに問題とはならないと考えられ る.

(4) 促進中性化試験および促進塩分浸透試験の結 果, 在来コンクリートおよび高流動コンクリ 一トの中性化速度は小さく, 塩分浸透速度も 小さい。一方，中性化残りを考慮して鉄筋腐 食に対する抵抗性を確保するためには，外部 からの塩化物イオンの侵入やフリーデル氏㙁 の分解が予測される場合には鉄筋かぶりを $28 \mathrm{~mm}$ 以上，それらが予測されない場合には $16 \mathrm{~mm}$ 以上とすることが望まれる.

(5) JIS A 1304 基準に基づく耐火試験の結果, 在来 コンクリートおよび高流動コンクリートの耐 火性能は概ね高いことがわかった。一方, わ が国のトンネル火災を想定した合理的な加熱 曲線については今後の研究が望まれる.

以上の知見から，コンクリートにひび割れなどの 欠陌がない場合のセグメント用コンクリートの透水 性, 塩分浸透性, 乾燥収縮, クリープ, 中性化を指 標にした基本的な耐久性能および而火性能は，概ね 把握できたと考えている. 今後は, トンネルの用途 に応じた使用環境条件を想定して，ひび割れなどの 欠陥を有する場合のセグメントの耐久性能を検討す る所存である. 


\section{参考文献}

1) 土木学会 : トンネル標準示方書(シールド工法編)・同 解説, p.25, 1996.7 .

2）土木学会・日本下水道協会共編 : シールド工事用標準 セグメント, p.357, 2001.7.

3）高見 敬一, 近藤 茂, 中道 拡, 渡辺 晴朗: 名古屋市 高速度鉄道のシールド工法について, 土木学会 第 1 回トンネルエ学シンポジウム, pp.65-85, 1962.6.

4) 前揭 1), pp.65-69

5) 例えば, 東京湾横断道路(策)，(財）土木研究センター： セグメント用コンクリート耐久性試験報告書, 1991.8.

6) 例えば, 工藤 泉, 阿部 廣二, 石倉 謙司, 吉田 幸司 : 耐久性と防食に関する研究(東京湾横断道路シールド トンネル), トンネルと地下, Vol.23, No.11, pp.45-52, 1992.11.

7) 例えば, 乾広海, 上根 善数, 杉原和彦, 田底 成智: 既存地下鉄構造物の中性化深さに関する考察, 土木学 会第 49 回年次学術講演会, V-237, 1994.9.

8）例えば, 伊奈 昭二, 水野 智雄, 神村 幸秀, 渡辺 敬 一: 平板型RCセグメントの超音波伝播速度と中性化 について, 土木学会第 50 回年次学術講演会, V-118, 1995.9.

9) 花見和則, 松裏寛, 宇野洋志城, 小泉淳: シール ド工事用セグメントへの高流動コンクリートの適用 研究, コンクリート工学論文集, Vol.12, No.1, pp.63-73, 2001.8.

10）清水 幸範, 山田一夫, 木村 定雄, 宇野洋志城, 秋 田谷 聡: セグメント用高流動コンクリートの特性(1), 土木学会第 54 回年次学術講演会, VI-50, 1999.9.

11) 前掲 2), pp.358-360

12) 日本建築学会: 建築工事標準仕様書・同解説(JASS5), p.172, 1997 .

13) 土木学会: 平成 11 年版コンクリート標準示方書-耐久 性照査型-(施工編), pp.11-14, 2000.1.

14）日本建築学会: 高耐久性鉄筋コンクリート造設計施工 指針(案) ・同解説, p.84, 1991.

15) 岸谷 孝一, 西澤 紀昭, 他編 : 塩害 (I), コンクリー 卜構造物の耐久性シリーズ, 技報堂, pp.29-34, 1986.5.

16) 土木学会: 高流動コンクリート施工指針, コンクリー トライブラリー93, p.30, p.40, 1998.7.

17) 前掲 13), pp.9-19

18）日本コンクリート工学協会: コンクリート診断技 術’01(基礎編), pp.32-65, 2001.3.

19) 村田 二郎: コンクリートの水密生の研究, 土木学会 論文集, 第 77 号, pp.59-99, 1961.

20) 花見和則, 松裏 寛, 宇野洋志城, 小泉淳: 高流動 コンクリートを用いたシールドエ事用セグメントの 品質, 土木学会論文集, No.658/VI-48, 2000.9.

21）笠井 芳夫, 池田 尚治, 編著: コンクリートの試験方
法(下), 技術書院, pp.148-151, 1993.6.

22）西 晴哉, 大塩 明, 曽根 徳明, 城國 省二: コンクリ 一トの海水に対する水密性, 小野田セメント研究報告, Vol.32, No.2, pp.140-153, 1980.

23) Bureau of Reclamation: Concrete Manual 8th ed., 1977.

24）宇野洋志城, 中川 岳, 弘中 義昭: 二・三成分系セ メントを用いた高流動コンクリートの耐久性, 土木学 会第 50 回年次学術講演会, V部門, pp.1110-1111, 1995.9.

25) 日本コンクリート工学協会 : JCI-SC5 硬化コンクリー ト中に含まれる全塩分の簡易分析方法, コンクリート 構造物の腐食・防食に関する試験方法ならびに規準 (案), pp.39-42, 1991.4.

26）前掲 2), p.289

27) 前掲 2), pp.394-395

28）前掲 14), p.85

29) 例えば, 土木学会: 平成 8 年制定コンクリート標準示 方書(施工編), pp.60-61, 1996.3.

30) 日本工業規格 : JIS A 1129 「モタルおよびコンクリ 一トの長さ変化試験方法」, 1993.

31) 前掲 14), pp.88-89

32) JIS原案 : コンクリートの圧縮クリープ試験方法(案), コンクリート工学, Vol.23, No.3, pp.55-56, 1985.3.

33）前掲 14), pp.179-184

34）例えば, 梅沢 健一, 岡沢 智, 堀部勝芳, 中川脩: 高流動コンクリートの強度および耐久性に関する研 究, コンクリート工学年次論文報告集, Vol.14, No.1, pp.959-964, 1992.

35）佐伯 竜彦, 大賀 宏行, 長瀧 重義: コンクリートの 中性化の機構解明と進行予測, 土木学会論文集, No.414/V-12, pp.99-108, 1990.2.

36) 前掲 18), p.34

37) 岸谷 孝一, 小林一輔, 樫野紀元, 宇野祐一: 塩化 物を含むコンクリート中における鉄筋腐食と中性化 との関係, コンクリート工学論文集, Vol.2, No.1, pp.39-49, 1990.7.

38) 日本コンクリートエ学協会 : コンクリート技術の要 点’96, pp.66-67, 1996.9 .

39）武居 泰: 高強度コンクリートの耐火性能に関する最 近の研究, コンクリートエ学, Vol.31, No.9, pp.62-65, 1993.9.

40) 日本工業規格：JIS A 1304 「建築構造部分の耐火試験 方法」, 1994.

41）木村 定雄, 守山 亨, 宇野 洋志城, 清水 幸範: シー ルド工事用セグメントの表面の微細構造, トンネル工 学研究論文・報告集, Vol.12, 論文-15, 2002.11.

42) ZTV-TUNNEL: Zusatzliche Technische Vertragsbedingungen und Richtlinien für den Bau von Straßentunneln, Teil 1, Geschlossene Bauweise 
(Spritzbetonbauweise), Ausgabe 1995.

43) Directorate-General of Public Works and Water Management Civil Engineering Division Tunnelling
Department(R.W.S.): FIRE PROTECTION FOR

TUNNELS, Document nr.:GT-98036a 98-CVBR1161a, 12 March 1999.

(2002.2.12 受付)

\title{
DURABILITY AND FIRE-RESISTANCE OF CONCRETE APPLIED TO SEGMENTAL LININGS FOR SHIELD TUNNELS
}

\author{
Sadao KIMURA, Naotoshi OKAMURA, Yoshiki UNO, Yukinori SHIMIZU \\ and Atsushi KOIZUMI
}

Recently there has been a tendency to omit a secondary lining, depending on the use of shield-tunnels, in order to reduce construction costs. However the experience in non-secondarily-lined tunnels is not abundant. It is also hard to say that alternative measures are being adopted after having thoroughly clarified the functions of the secondary lining, such as a deteriorating performance of a primary lining in the long term without the secondary lining. Such is the case that segments as the primary lining have to compensate the loss of the function of the secondary lining. On the other hand, there seems to be little data or information about the durability of the secondary lining. This study has grasped through experiments durability and fire-resistance ability of reinforced concrete segments that will be used as a lining without a secondary one. It proved that the concrete used for the segments possessed high durability and fireproof ability. 